\title{
Cultural landscapes in the lower Danube area. Experimenting tell settlements
}

\author{
Dragos Cheorghiu \\ Centre of Research, National University of Arts - Bucharest, Romania \\ Gheorghiu_dragos@yahoo.com
}

\begin{abstract}
In archaeological research Chalcolithic tells are generally approached as distinct, decontextualized, architectural objects, separated from the other cultural traits which form a whole dwelling complex. A goal of the present paper is to present tells as part of a larger dwelling strategy, under the form of a cultural landscape structured by numerous rites of passage and modelled with fire. The experimental and experiential approaches to understanding the process of construction and of intentional firing, as well as the importance of firescapes in the construction of collective memory are discussed.
\end{abstract}

IZVLEČEK - Arheološke raziskave halkolitskih tellov so ponavadi usmerjene v dekontekstualizirane arhitekturne objekte, ločene od drugih kulturnih elementov, ki sicer definirajo naselbinski kompleks. V razpravi predstavljamo tell naselje kot element širše poselitvene strategije v kontekstu kulturne krajine, ki jo strukturirajo številni rituali povezani z ognjem. Analiziramo eksperimentalne in izkustvene pristope $k$ proučevanju gradnje in namernega požiganja ter njihovega pomena pri oblikovanju kolektivnega spomina.

KEY WORDS - experiment; tells; separation; cultural landscapes

\section{Introduction}

Recent decades have witnessed the rise of landscape archaeology, an archaeological sub-discipline which has contributed to a nuanced understanding of the past. A relatively recent trend, based on the spatial experimentation of virtual landscapes reconstructed in 3D (Forte et al. 2003; Forte 2005; Campana and Forte 2006), or GIS (Llobera 2001), represents a step forward in the evocation of ancient territories, but in spite of its contextualized knowledge, it remains a disembodied intellectual exercise (contra Horner 2001), missing the possibility of an authentic approach to the materiality of the environment, as well as to the sensory/motor bodily experience of the populations studied. In this respect, the studies in phenomenological archaeology of the end of the 20th century (Tilley 1994; Edmonds 1999) have given rise to a more sensitive interpretation (Tilley 2004; Thomas 2006; Thomas and Brück 2006; Hamilton et al. 2006).
Consequently, besides visual experience, the embodied knowledge of the direct sensory experience of the context, representing the experience of the construction of the meaning in the field by relating fragments of geomorphology with cultural traits, and the experience of their materiality, would influence the interpretation of $3^{\text {rd }}$ millennium $\mathrm{AD}$ archaeologist (for the dangers of a modern-centrist interpretation in explaining personal phenomenological experience see Hodder and Hutson 2006.119-121), and would direct archaeological research to motivating directions in interpreting some vague concepts like space, water, fire or dwelling (i.e. landscape) which cannot be explored in depth by current scientific methods.

The present paper tries to implement a mixed approach between archaeological experiment and the sensory embodied experientialism of relevant fea- 
tures of the context, to identify and (partly) explain a number of patterns which define the landscape of the Lower Danube area in the $5^{\text {th }}$ millennium BC. Through the study of the relationship between the body and the structured, built environment (Bourdieu 1977.89; Bell 1992.98) of Chalcolithic communities, landscape is approached as a ritualised space (cf. Turner 1975.69).

\section{Experiment - experientiality}

When approaching a complex and fluctuating concept like the prehistoric landscape, one can experiment on the limits of the current methodologies, as well

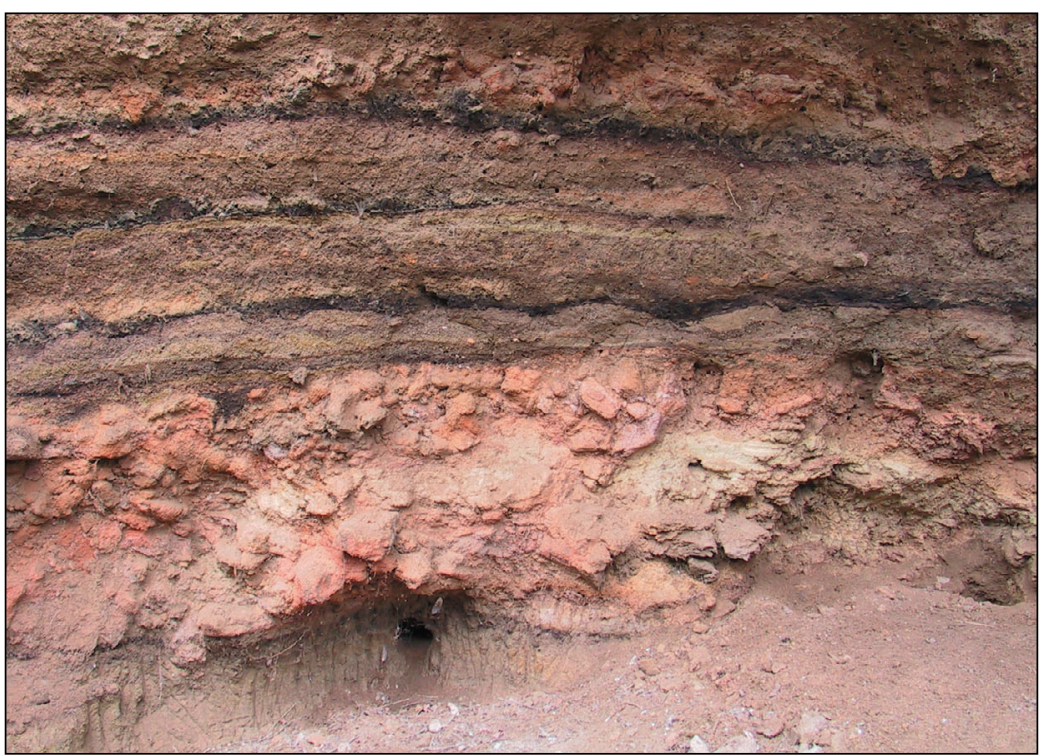

Fig. 1. Harsova tell, the Boian layer of fired houses (all the photos by D. Gheorghiu). as of the constraints of the representation of the scientific discourse, a state of fact challenged by postprocessualism.

As a reaction to the limitations of ethnographic narrativity, as early as the '80ies, an "allegorical anthropology" (Tyler 1985; Clifford 1980) was created, but the first attempt to use allegory in an archaeological text dates back to the '90ies (Tringham 1992; Edmonds 1999; Bailey 2000); the latter exploited fiction and poetic texts ascribed to diverse imagined characters in order to transcend the limits of the disembodied intellectual experience of scientific description.

One solution to this problem would have been experimental archaeology, but it was limited as an academic discipline (Reynolds 1999; Mathieu 2002; Jeffrey 2004) to operating only within material culture, and any sensorial relation with the material world was accepted only at the level of objects (see Hurcombe 2007). Consequently, the study of non-material subjects like the experience of a place (Tamisari and Wallace 1988), or of landscape, were approached through the phenomenological perspective of the experiential 'archaeologies of inhabitation', promoted by post-processualists, now criticized for having produced hyper-interpretive texts (Fleming 2006), but which generated fertile sources of inspiration like theatre/archaeology (Shanks and Pearson 2001).

For my research on the cultural landscape in the Lower Danube area, I began with an experimental ar-

chaeology approach, by inferring a set of hypotheses (Cavulli and Gheorghiu 2008) which should have been accepted or rejected after some "clearly defined procedures and reasoning" (Jeffrey 2004.13; see also Kelterborn 1987), in order to reconstruct architectural structures and processes (the combustion of these structures).

Since I was physically involved in the making of different kind of objects (from ceramic vases to wattle and daub houses), I became aware that the division in the current archaeological research (i.e. scientific experiment vs. sensory experience) is not possible, since nobody can experiment without also embodying the sensory experience of the action.

By avoiding experiential knowledge, one reduces the odds of understanding the construction of past reality, like the somatic mode of awareness. Due to the limitations of scientific experimentation and therefore reconsidering the importance of the body as the site of lived experience (Joyce 2005), I consider that the phenomenological knowledge resulting from experimentation should be used, with caution, as a thinking through the body instrument (see Hamilakis et al. 2001; Hamilakis et al. on-line), when it can reveal behavioural elements not observed before.

Complex scenery like a cultural landscape cannot be understood without a combination of the measurable results of archaeological experiment and the (subjective) personal experiential embodiment of a cultural phenomenology (Csordas 1999) generated by geomorphology and the built environment. 


\section{The geographic context and dwelling strategies}

The Lower Danube is a geographical area which includes the low wetlands from the north banks of the Danube, between the Olt River and the Dobroudja plateau and the flat South Romanian Plain (Cotet 1976), with a landscape characterised by medium high loess terraces and lower areas acting as buffers for the cyclical floods of the hydrosystem. This cyclical wetland (Gheorghiu 2006a), without significant vertical dominant locales, was progressively settled during the Neolithic and Chalcolithic along its river valleys (Comsa 1987; 1994; Davison et al. 2006).

At the beginning of the $6^{\text {th }}$ millennium $\mathrm{BC}$, the intense dynamism of the Early Neolithic Starčevo-Criş or Dudeşti populations (Bailey et al 2002), probably determined also by the lack of balance of the hydrographic system of the Danube, left in the archaeological record only thin horizons of dispersed areas of dwelling (Comsa 1997; Bailey 2000).

In the Early Chalcolithic, along the flat, dispersed settlements, a new form of occupation of the land emerged in the Lower Danube area, i.e. the overlapped, compact settlements or tells (Morintz 1962; Dumitrescu 1965; 1966a; 1966b; Comsa 1997; Andreescu et al. 2001). During the development of the Gumelnita tradition, Phase A1 4700-4350 BC, and Phase A2 4500-3950 BC (Bem 2000-2001.43), this mode of dwelling will spread north along the river valleys, and in the final phase, B1, tell settlements are documented on islands (Cascioarele Ostrovelul, Dumitrescu 1965), terraces (Brailita, Hartzuchi and Dragomir 1957; Teiu, Nania 1967) or levees (Liscoteanca and Largu, Dragomir 1959). Unfortunately, the partial excavation of most of the tells, as well as the insufficiency of advanced research to document all the types of Chalcolithic dwelling in the Lower Danube area, compared to other geographical zones (see Menze et al. 2006; ArchAtlas: Tellspotting, on-line), does not allow the creation of a holistic image of the complexity of the Chalcolithic dwelling, but the emergent advanced research in some areas [http://map.cimec.ro/LocalizareExa $\mathrm{cta} /$ mapserverEn.html] gives hope that in the near future this deficiency will be overcome, and our knowledge of the relationship between settlement and landscape will be supplemented.

\section{Landscape}

In defining 'landscape', one faces the difficulty of working with a poloysemic concept. Since a landscape is a cultural (or social, see Chapman 1997) construct, structured in accordance with the purpose of the analysis, I choose from the multitude of definitions those which can be applied to the theme and method of the present paper, and describe landscape as a surface which shall be passed through.

In a diachronic perspective Stoddart and Zubrow (1999) perceive landscape as a palimpsest of cultural levels; the same viewpoint of a "continued" (Bailey 1997.49) "surface over which people moved and within which they congregated" is shared by Barrett (1991.8), and by all who see it as "an arena for ritual or ceremonial activity" (for an extended bibliography see Knapp and Ashmore 1999).

Tilley (1994.25) looks upon landscape as representing the "physical and visual form of the earth as an environment and as a setting in which locales occur, and in dialectical relation to which meanings are created, reproduced and transformed". He continues by saying that moving across a landscape is an art, especially approaching the cultural dominant locales from the "right (socially prescribed) $d i$ rection" (Tilley 1994.28).

All the defintions mentioned insist on the cultural attributes of the landscape/s; consequently, I chose the syntagm 'cultural landscape' (first used by Sauer

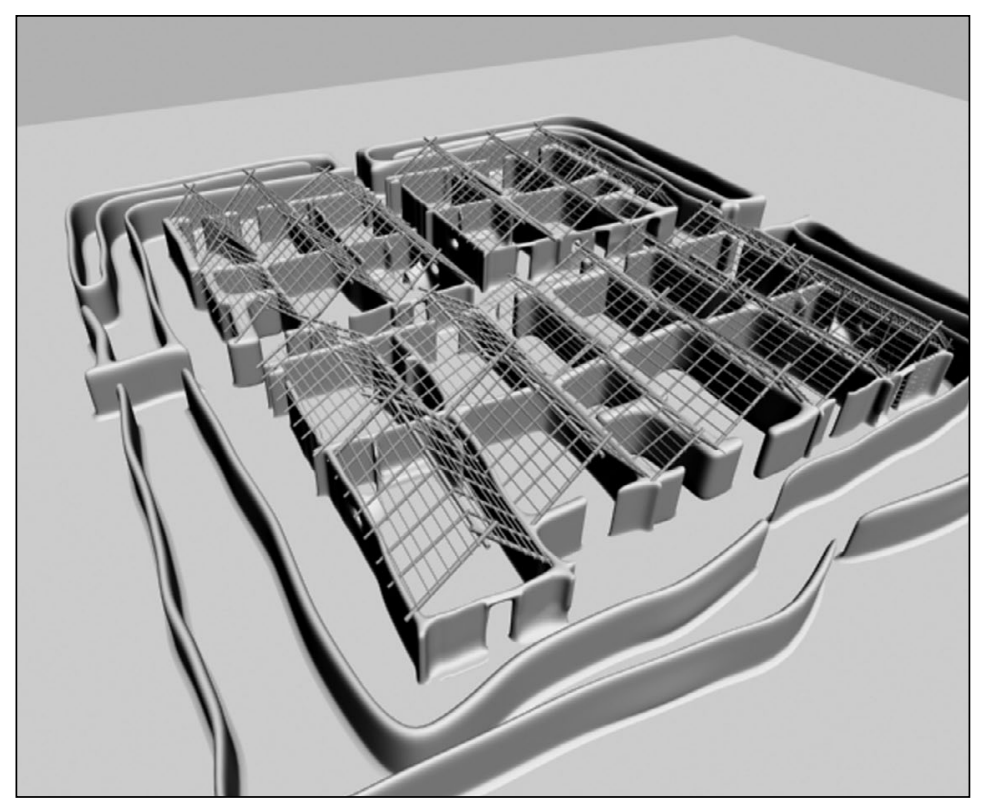

Fig. 2. Virtual reconstruction of Ovčarovo tell by Bogdan Dumitrescu (after Todorova 1982) 
1925) to illustrate in the Lower Danube area the mix of geomorphology and cultural products such as tell settlements.

\section{Tells}

There are several definitions of tells (Sherratt 1983; Chapman 1997; Kotsakis 1999) and approaches (like the built /un-built space; Chapman 1991a; 1991b), social action (Chapman 1997) or visual relations (Bailey 1997) which depict them as a cultural and natural alluvium consisting of a cumulative, ordered and repetitive mode of dwelling in the same place. In my definitions, I asserted the character of separation from the rest of the environment by means of different architectural fea-

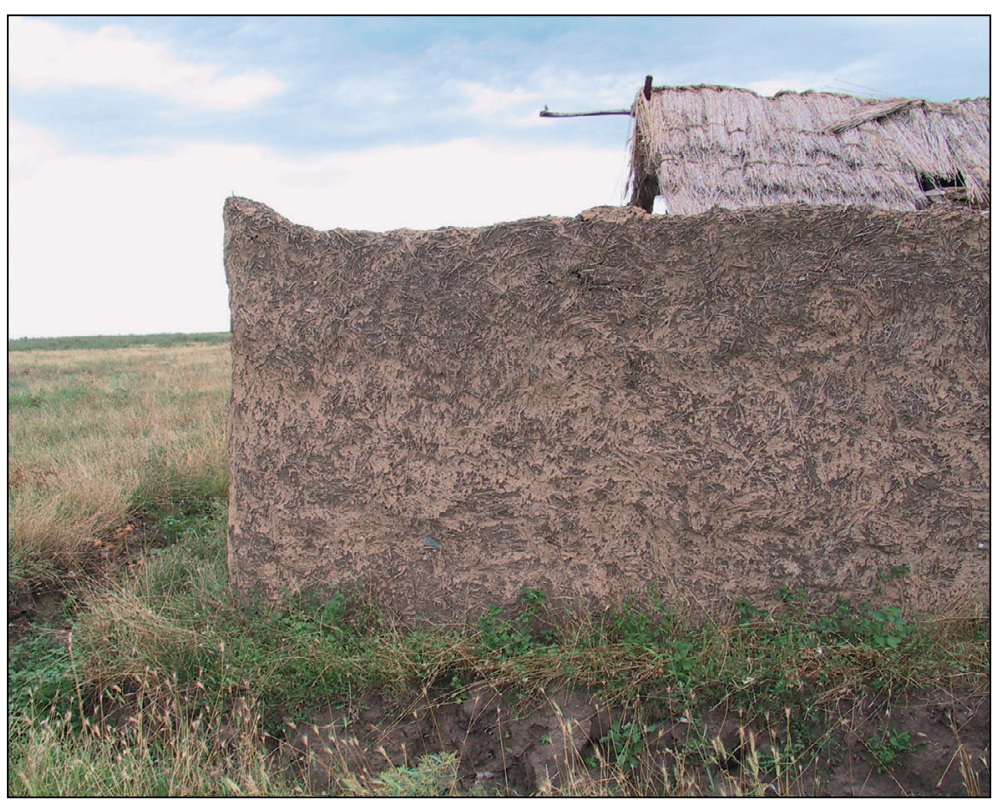

Fig. 3. A tell settlement surrounded by a ditch and palisade, Vadastra 2003. tures (Gheorghiu 2002a; 2003a; 2006a; 2006b), or geomorphological elements, a trait which I will approach in the present paper from an experiential angle.

A characteristic of the South Eastern Neolithic Europe dwelling is the fired levels of habitation which are supposed to have been intentional (see Tringham 1992; Stefanović 1997; 2002; Chapman 1999). Similar horizons of combustion are found in the Lower Danube area at the majority of tell settlements (see Dumitrescu 1986; Nania 1967; Mihailescu and Ilie 2004.75) (Fig.1).

\section{Materials}

When approaching tells from the perspective of site catchment, an aspect constantly neglected is the materiality of the built environment. The building of a tell implied the use of diverse basic materials whose presence in the landscape, and subsequently in the symbolism of the social group, had a significant cultural value. A tell was the result of the blending of clay with water, wood and processed vegetation (like chaff, cereal straws, reeds or twigs), being therefore a cultural landscape, since it was the result of a process of subtraction and re-composition of the materials from the natural landscape. In this perspective a tell acted like an attractor of the materials from the surrounding landscape and became a semiotic package of the materiality of the landscape, representing a re-ordered Nature, domesticated by means of cultural rules (Gheorghiu in press a). In

time, ceramics, an artificial material resulting from the combustion of houses or palisades, were added to the list of natural materials.

\section{Stages of separation}

Gumelnita tells had good visibility - tell settlements were located 'to see and to be seen', (Gheorghiu $2003 b$ ), visually dominating the territory and being the dominant visual attractor of the territory; in other words, controlling the surrounding landscape from inside and outside the segregated built space.

There was a small number of types of location adopted for tell building: high terraces, anastomosed terraces and islands, determined not only by pragmatic factors like low flood risk, high sun exposure and low exposure to the prevailing winds, but also by the motivations of seclusion and visibility. Two main types of separation were identified (Morinz 1962): on one side, when positioned on protruding terraces; and around the built perimeter, when positioned on anastomosed terraces or islands. So the particular positioning of tells as interfaces between two kind of landscape, the dry land and the wetland, required a cultural and a natural separation depending on the geomorphology of the place chosen.

Being a sort of storehouse/wood shed/barn/dwelling, an architectural object designed mainly to store, an inference arises from the proportions of the built and un-built surface (Chapman 1991a; 1991b) (Fig. $2)$; tells probably represented a solution of econo- 
mic adaptation to the cold season, but such a specialised way of dwelling required the existence of complementary ways of inhabiting. In this perspective, tells will be viewed not as the only way of dwelling in of Chalcolithic populations, but as a part of an extended mode of dwelling, comprised of seasonal open settlements (see Nania 1967; Gheorghiu 2006a) and necropoleis (for an extended bibliography see Lazar and Parnic 2007) which formed a holistic cultural landscape (see Knapp and Ashmore 1999).

For most of their part neglected

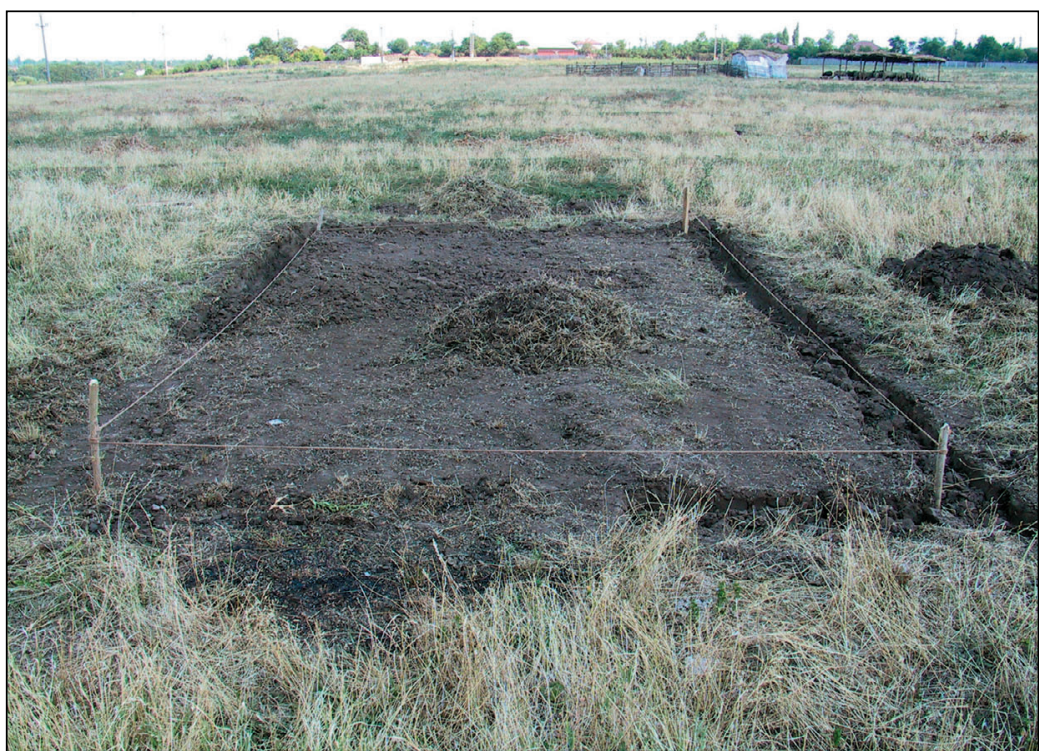

Fig. 4. Foundation ditches for a wattle and daub house, Vadastra 2003. by archaeological research, the open (i.e. non-separated) settlements and workshops subordinated to a tell (both as location and visibility) were probably seasonal places for processing the products of the wetland and dry land. This pattern emerges as early as the Early Chalcolithic in locations like Radovanu (Comsa 1997), Tangaru, Uzunu (all belonging to the late Boian tradition), Burdusani-Popina, ValeaArgovei-Vladiceasca (all belonging to the Gumelnita tradition), and supports the image of the tell as a packed place (cf. Chapman 1991b) and a temporary place of seclusion.

The cliffs of the terraces, as well as the marshes, the lakes or rivers which separated tells from the rest of the landscape were obstacles to the human body. In a similar way, the internal space of the tell offered a hierarchy of discontinuities because of the various boundaries created by its architecture (see Hillier and Hanson 1984.144; Grahame 2000.11). To have access to the inhabited space inside the tell, one had to pass through a series of footbridges, gates, and doors which underlined the rituality of passage from one space into another (Gheorghiu 2003a).

In this perspective it is reasonable to consider the archaeology of tells as being an archaeology of the rites of passage (separation being a rite in itself; van Gennep 1960) materialised in the archaeological record in the form of ditches and foundation trenches which delimited the dwelt an area separated both in a physical and symbolic way.

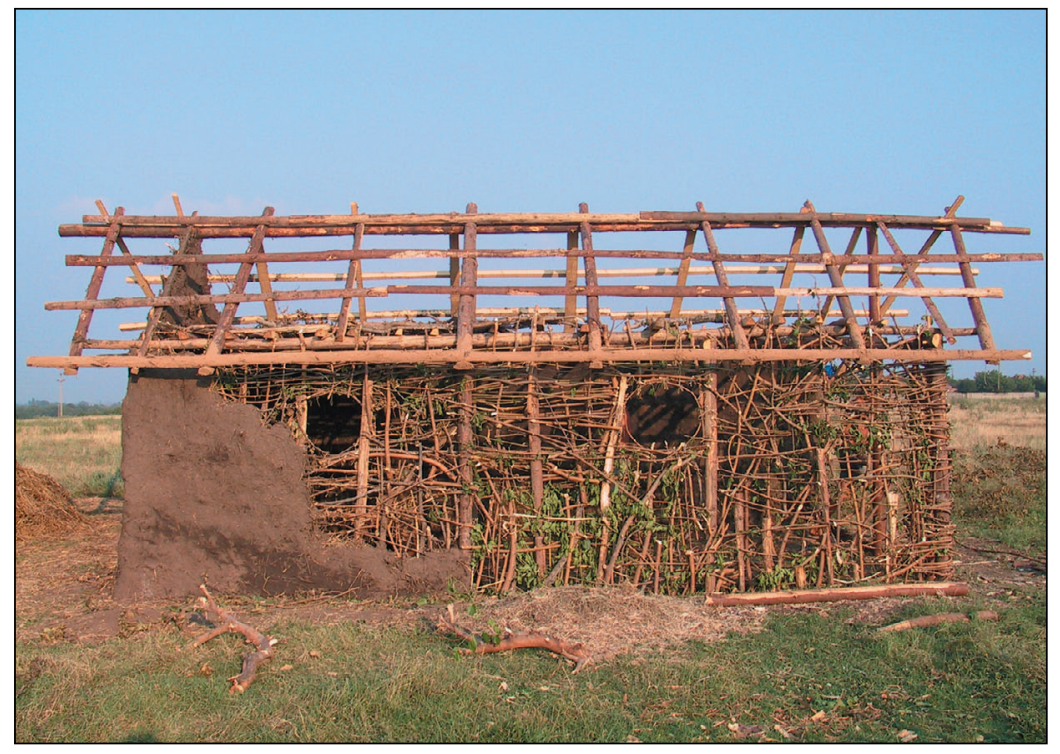

Fig. 5. The plaited structure of walls. Vadastra 2005.
The first stage of separation achieved by means of perimeter ditches and (sometimes) of palisades was between the inner dwelling space on the one hand, and the external (Fig. 3), cultural and wild spaces, like seasonal settlements, workshops, necropolis, cultivated lands and wilderness, on the other hand. Probably the act of separation of digging a ditch into the loess soil produced the clay and the container for the preparation of house daub (Gheorghiu 2006b). The separated, inhabited area of the tell was divided into several standardised rectangular enclosures 
(positioned in two rows in the simplest variant of the first phase of the dwelling, as seen at Radovanu; Comsa 1997), an architectural design which implies the existence of a predetermined plan (cf. Todorova 1984 for Bulgarian tells), a tell settlement planned as a single architectural object, composed of a series of habitation units, built at the same time.

Such an organisational decision suggests that social difference was not encoded in the dimensions of the houses, but probably in their position (within a back/ front - left/right symbolism) within the master plan in relation to the main access of the ditch/palisade passage, and consequently, with the cultural landscape.

Not only was the process of construction structured according to rites of separation, but also the stages of the chaines-opératoires used to process the building materials had the role of separating them from their natural context and shapes. An example could be the removal of bark and shaping of tree trunks for use as beams or posts. Another rite of separation from their natural condition was performed when the processed materials were set in order according to two kinds of pattern: one natural (i.e. spatial orientation in relation to earth, sun, water and winds) and one cultural (i.e. the geometry of the built forms).

An additional rite of separation, this time within the community, was created when the foundation trenches of the houses were dug inside the secluded perimeter of the settlement (see Todorova 1982.81, Fig. 41; Popovici and Railland 1996-1997.24; Marinescu-Bîlcu et al. 1997.68; Randoin et al. 19982000.231, Pl. V) (Fig. 4). Ethnographic data from Vadastra village, as well as the experiments I carried out during the last few years, support the importance of the foundation trenches in the process of construction, because by filling the trench with soil pressed around the posts and the plaited twigs which formed the wattle and daub walls, the fastening of the vertical structure of the wall was improved.

One can imagine that the planting of the posts and of the plaited twigs was part of the process of de-

signing a cultural landscape with a possible symbolic meaning representing a separate cultivated/domesticated/nature (Fig. 5).

Combustion was probably a final rite of separation when a building, or all the settlement were fired, and the crushed wattle and daub structures were transformed into ceramic layers, later levelled to create a new ground surface for a new dwelling. Ceramics became a material related to dwelling identity, an interface between two episodes of the inhabitation of a place.

Despite the discontinuities of inhabitation, tells can be seen as immobile places within a landscape in flux (see Bailey 199.54; Andreescu et al. 2001), where the next static cultural element was the necropolis.

Although a visual reciprocity existed between tell and necropolis (see Bailey 1997.51; Lazar and Parnic 2007.137), these two modes of social storage were separated by geomorphic elements. For example, at the Gumelnita eponymous site (Dumitrescu 1996) or Mariuca (Lazar and Parnic 2007), both situated in the microzone of Mostistea River, the tell and its necropolis were separated by a deep valley. At Cāscioarele-D'aia parte, the tell was positioned on an islet, separated by marshes cyclically flooded from the necropolis on the lake terrace (Şerbannescu and Sandric 1998). To access the Gumelnita or Mariuta necropolis, one should walk off the terrace, cross a marshy valley and then walk up the terrace again; in other words, undergo the experience of a 


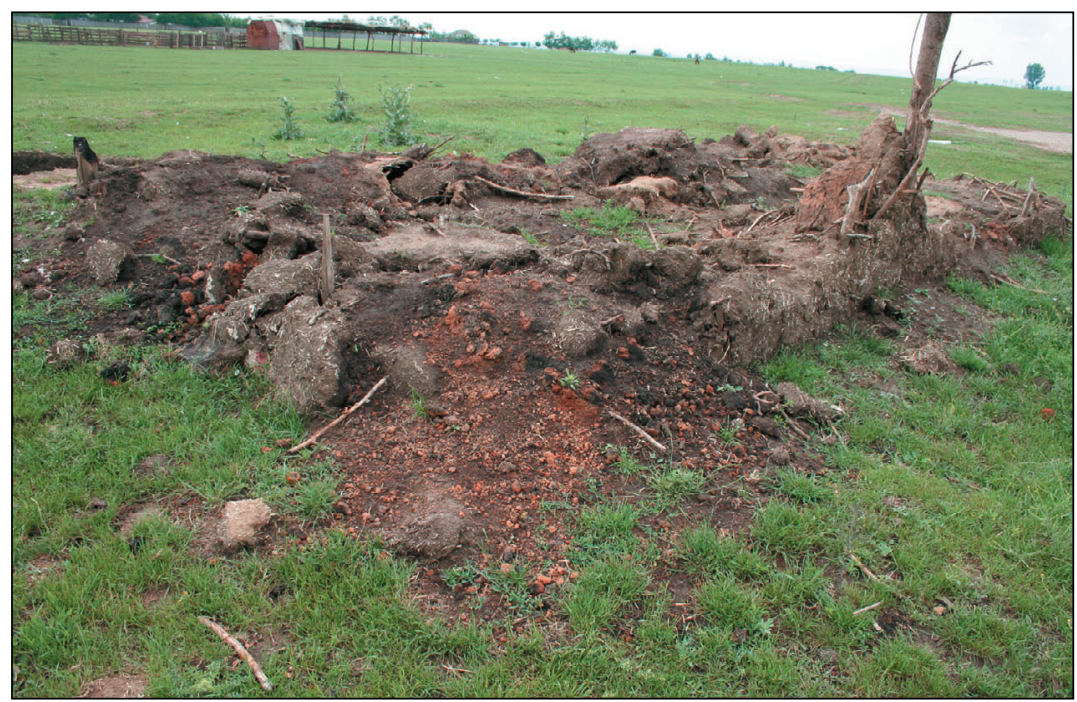

Fig. 7. The fired house four months after the collapse of the walls. Vadastra 2006.

rite of passage with three stages well defined visually and physically (see Van Gennep 1960; Turner 1995). Here, the valley separates the cultural landscape into two locales with different statuses.

A number of the necropolises were positioned west of the tell (at Cāscioarele-D'aia parte, Vārāşsi-Grādiştea Ulmilor, Sultana-Malu Roşu in the Lower Danube area, and at Durankulak, Goljamo Delcevo, Radingrad, Vinica in Bulgaria, see Lazar and Parnic 2007. 140), a spatial organisation that could have been the result of a symbolic decision related to rites of separation.

\section{Firescapes as part of the cultural landscape}

While many of the tell houses show signs of combustion, there are no regular patterns of occurrence, except for at Gumelnita final phase B, when almost all the Lower Danube tells were abandoned after being fired.

Chapman (1999.122) remarked that house combustion does not represent a unified phenomenon, and could have various causes, intentionality being one among many others. The experiments I conducted during the last few years support the idea that a wattle and daub dwelling was 'built to be fired' (Gheorghiu in press b) only after being filled with sufficient fuel, and after taking ad- vantage of strong air turbulence; the functional openings in the walls and ceiling then create a draught to support the combustion of the fireproofed ligneous material (Fig. 6).

After the wooden interior structure of the walls was consumed by fire, their negative shape was transformed into a set of draught tubes which improved the combustion process of the daub (Gheorghiu 2002b). During the combustion process, the architectural element which played the most important role was the foundation trench, because it delimited the built perimeter after the collapse of the walls. After the ligneous material had been consumed, the walls could have been pushed to fall inside the built perimeter to douse the fire; generally, they fractured above the ground at variable heights, thus offering a visible image of the separation of the dwelt space (whose perimeter is therefore well preserved and visible above the ground) from the rest of the settlement space, in this fashion creating a post-habitation landscape (Fig. 7).

When perceived from this diachronic perspective as a palimpsest landscape formed as the result of ritual overlapping episodes of dwelling, combustion, abandon and return, in a kind of eternal return, tells reveal their pulsatory nature of attracting and transforming landscapes with fire.

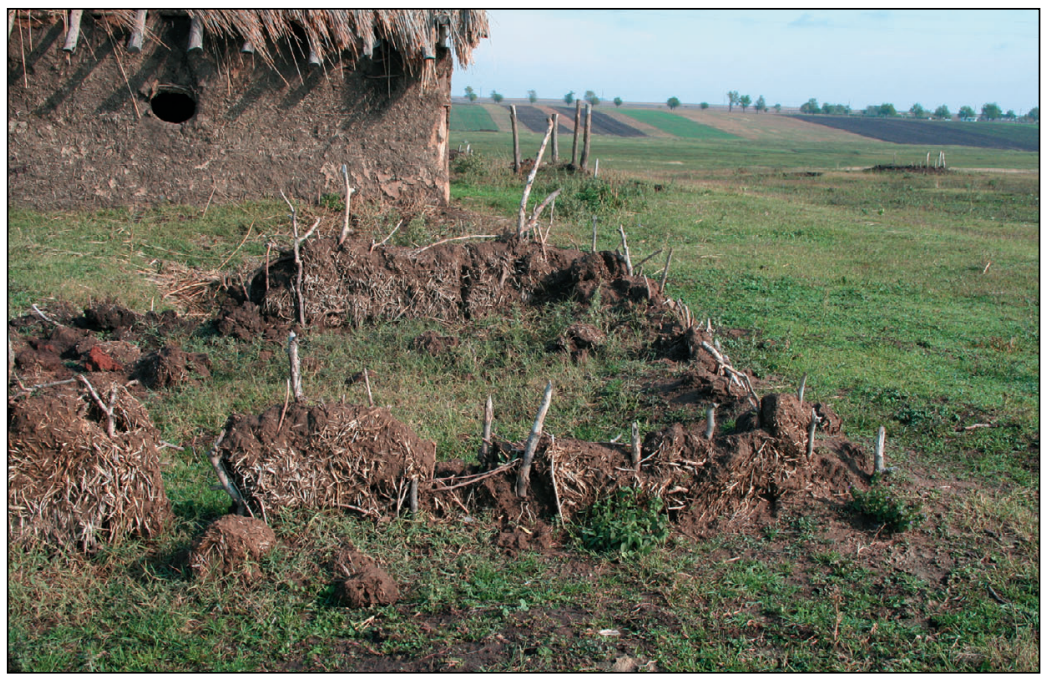

Fig. 8. The weathered walls of a wattle and daub house built in 2004. Vadastra 2007. 
Other experiments on the decay of wattle and daub structures after the abandonment of a settlement without burning houses (by dissolution of the clay and by mechanical fracture due to human and animal action), revealed a similar pattern of deconstruction (Fig. 8), the process of decay of the wattle and daub walls being stopped at variable heights from the base of the walls by the mechanics of the foundation trenches, which produced a piling of the material along the perimeter of the trenches. We can infer that a post-habitation landscape shaped by the foundation trenches was percei-

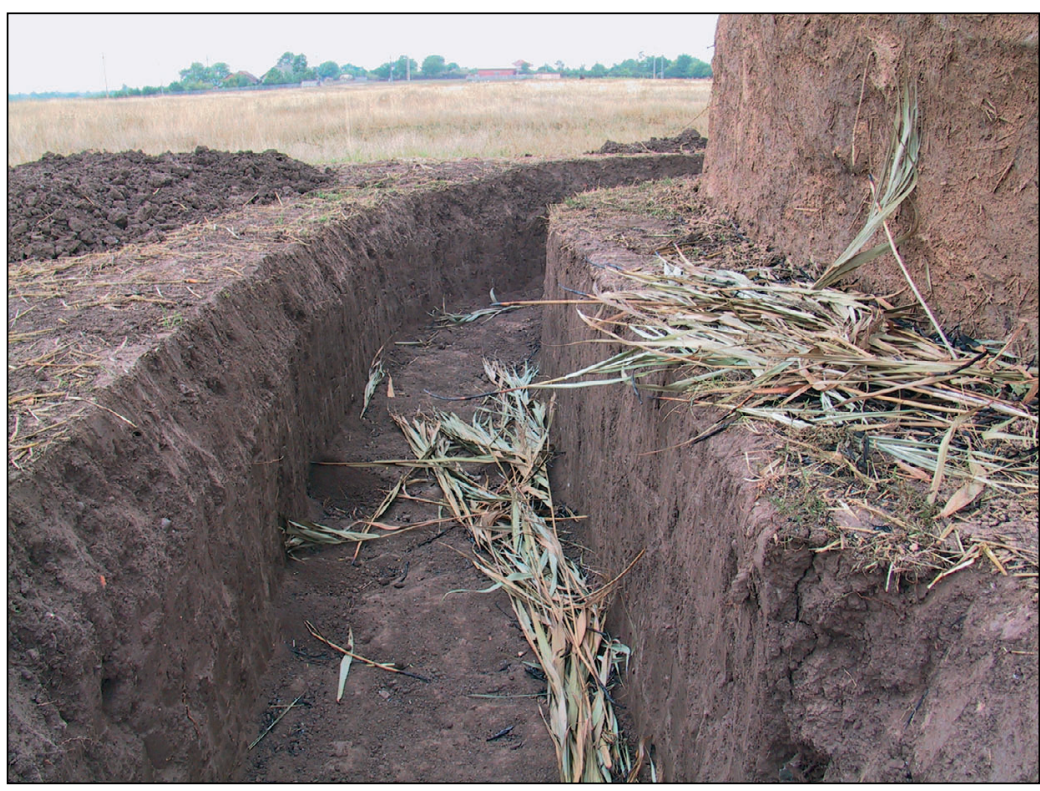

Fig. 9. A perimeter ditch surrounding a palisade. Vadastra 2004. ved by Chalcolithic people as a landscape of abandonment, which preserved the coordinates of the previous plan of inhabitation.

\section{Conclusion. Experiencing ancient mind and landscapes}

In an attempt to understand the relationship between the minds and landscape of prehistoric populations, I employed a mix of experimental and experiential approaches, functioning as an instrument of thinking through the body. A whole cultural phenomenology (Csordas 1999) was therefore created through the crossing of valleys, slopes, ditches, footbridges or watching combustion processes, since they all subdued the body to an effort of control and awareness.

The passing through was revealed to be the process specific to experimenting on the cultural landscape of the tells: after a relatively exhausting crossing of the valleys, surrounding waters or marshes, the performer finally arrived in front of the tell; here, searching for the entrance his/ her body was oriented according to the master plan of the dwelling, then followed the crossing of the temenos, the ditch (Fig. 9), then of the palisade, before reaching the true interior space, where narrow corridors between

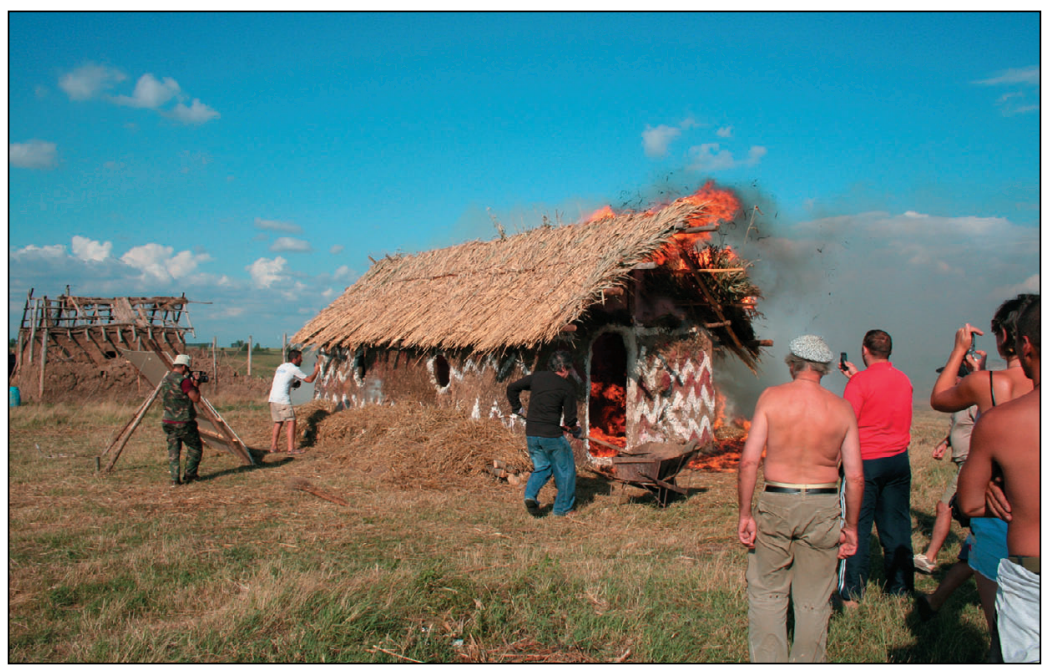

Fig. 10. Watching the combustion of a wattle and daub house. Vadastra 2006. the household units reoriented and directed the body (but against the determinism of architectural structures on the human body, see Brück 2001).

As participants could experience, the technologies of building imposed bodily experience of the materiality of wild and cultural materials; the body treads and kneads the soft materials, and adjusts the solid ones, following geometric patterns. The firm geometry of the first levels of habitation in tells seems to have been a symbolic gesture of separation from the curved lines of the natural landscape.

When experimenting with the diverse techniques of acquisition and building, one could discover the remarkable analogies between plant cultivation and 
their processing on the one hand, and the construction of the house on the other: the performer plants the posts and the wattle in the foundation trench in a way similar to the planting of trees; plaits the wattle of the wall like baskets and mats; and fixes the clay on the vegetal structure in rows like building a vase. An equivalent kinaesthesia controls the cultural landscape: cultivation, the making of objects and the building of houses are made in the same symbolic way, which implies a coherence of meaning in the creation of the landscape. Furthermore, symbolic correspondence could be found between the different firescapes: the farming fire cycles or deforestation, the combustion of tells, and the sunset over the westerly necropolises produced an analogous sight.

Firescapes were not only economic practices, but also commemorative. The intentional deconstruction through fire of the tell settlements could have had a ritual significance in constructing the social memory of the group, as well as strengthening the social body: during the first moments of the blaze which consumed a house, the group of observers behaved as a single individual due to a shared emotion $\mathbf{1}$ (Fig. $10)$.
One advantage of using a combination of science and phenomenological experience to understand tells in context was the opportunity to experiment with the analogies existing between separate realities such as the mind and landscape: I experienced how an ephemeral event like a firescape was fixed in the memory of the social body, how it was fixed in the memory of a ceramic deposit, and how it was fixed in the cultural landscape.

\section{ACKNOWLEDGEMENTS}

I want to thank Professor Mihael Budja for kind help during the conference, Dr. Romeo Dumitrescu for financing the experiment of building and firing the house, and M. Bogdan Capruciu for re-ordering the English text. Last, but not least, my gratitude goes to the team of experimenters who worked with me at the Vadastra site: Marius Stroe, Catalin Oancea, Dragos Manea, Adrian Serbanescu and Stefan Ungurea$n u$, and to the village community who helped with people and materials. The experiments in 2005 and 2006 were financed by two CNCSIS grants (1612 \& 945).

\section{REFERENCES}

ANDREESCU R., MIREA P., APOPEI S. 2001. Valea Teleormanului, mediul si comunitatile umane in mileniul $\mathrm{V}$ a.Ch. In M. Neagu (ed.), In Honorem Silvia Marinescu-Bilcu 70 de ani. Cultura si Civilizatie la Dunarea de Jos 22. Calarasi: 141-150.

ARCHATLAS: Tellspotting on-line: http://www.archatlas. dept. shef.ac.uk/Tellspotting/TellsMain.php

BAILEY D. W. 1997. Impermanence and flux in the landscape of early agricultural South Eastern Europe. In Chapman J., Dolukhanov P. (eds.), Landscapes in flux. Central and Eastern Europe. Colloquia Pontica 3. Oxbow Books, Oxford: 41-58.

2000. Balkan prehistory: Exclusion, incorporation and identity. Routledge, London, New York.
BAILEY D. W., ANDREESCU R., HOWARD A. J, MACKLIN M. G., MILLS S. 2002. Alluvial landscapes in the temperate Balkan Neolithic: transition to tells. Antiquity 76: 349355.

BARRETT J. 1991. The Archaeology of social reproduction. In Barrett J., Bradley R., Green M. (eds.), Landscape, monuments and society: The prehistory of Cranborne Chase. Cambridge University Press, Cambridge: 6-8.

BELL C. 1992. Ritual theory, Ritual practice. Oxford University Press, Oxford, New York.

BEM C. 2000-2001. Noi propuneri pentru o schita a eneoliticului romanesc. Pontica XXXII - XXXIV: 25-120.

1 It is obvious that the significance of the event recreated was completely different from that of the past, but one can infer that the process of a house consumed by fire was a special event in the past. For a contemporary person the experience of the combustion of the house is at the same time traumatic and fascinating, the whole process of combustion of the house could be regarded as a stage of separation which impressed the public. In spite of its ephemerality the event was fixed in the memory of the participants. 
BRÜCK J. 2001. Monuments, power and personhood in the British Neolithic. Journal of the Royal Anthropological Institute 7: 649-667.

CAMPANA S., FORTE M. (eds.) 2006. From Space to Place: $2^{\text {nd }}$ International Conference on Remote Sensing in Archaeology. Proceedings of the $2^{\text {nd }}$ International Workshop, CNR, Rome, Italy, December 4-7, 2006 BAR IS 1568.

CAVULLI F., GHEORGHIU D. 2008. Looking for a methodology burning wattle and daub housing structures. A preliminary report on an archaeological experiment. Journal of Experimental Pyrotechnologies 1: 37-43.

CHAPMAN J. 1999. Deliberate house-burning in the prehistory of Central and Eastern Europe. In Gustafsson A., Karlsson H. (eds.), Glyfer och arkeologiska rum - en vanbok till Jarl Nordbladh. Gotarc Series A. Vol.3: 113126.

1997. Places and timemarks -The Social construction of prehistoric landscapes in Eastern Hungary. In Nash G. (ed.), Semiotics of Landscape: Archaeology of the Mind. BAR 661: 147-178.

1991a. Social inequality on Bulgarian tells and the Varna problem. In Samson R. (ed.), The Social Archaeology of houses. Edinburgh University Press, Edinburgh: 49-92.

1991b. The Early Balkan village. In 0. Grøn, E. Engelstad, I. Lindblom (eds.), Social space. Human social behaviour in dwelling and settlements. Odense University Press, Odense: 79-99.

CLIFFORD J. 1986. On ethnographic allegory. In Clifford J., Marcus G. E. (eds.), Writing culture. The Poetics and politics of ethnography. University of California Press, Berkeley: 98-121

COMSA E. 1997. Tipurile de asezari din epoca Neolitica din Muntenia. Cultura si civilizatie la Dunarea de Jos $X V: 144-164$.

1994. Asezarea Starčevo-Criş de la Dulceanca. Analele Banatului SN III: $13-17$.

1987. Neoliticul pe teritoriul Romaniei. Consideraţii. Editura Academiei. Bucharest.

COTEŢ P. V. 1976. Campia Romana. Studiu de geomorfologie integrate. Ceres. Bucharest.

CSORDAS T. 1999. Embodiment and cultural phenomenology. In Weiss G., Haber H. (eds.), Perspectives on embodiment. Routledge. New York: 143-162.
DAVISON K., DOLUKHANOV P. M., SARSON G. R., SHUKUROV. A. 2006. The role of waterways in the spread of the Neolithic. Journal of Archaeological Science 33: 641652.

DRAGOMIR I. T. 1959. Sapaturile arheologice de la Largu. Materiale VI: 499-503.

DUMITRESCU V. 1996. Gumelniţa. In Preda C. (ed.), Enciclopedia Arheologiei şi Istoriei Vechi a României II: 207-208.

1986. Stratigrafia asezarii-tell de pe ostrovelul de la Cascioarele. Cultura si civilizatie la Dunarea de Jos 2: 73-81.

1966a. Principalele rezultate ale primelor doua campanii de sapaturi din asezarea neolitica tarzie de la Cascioarele. Studii si Cercetari de Istorie Veche 16 : 215-237.

1966b. Gumelnita. Sondajul stratigrafic din 1960. Studii si Cercetari de Istorie Veche 17: 51-99.

1965. Principalele rezultate ale primelor doua campanii de sapaturi din asezarea neolitica tarzie de la Cascioarele. Studii si Cercetari de Istorie Veche 16: 215237.

EDMONDS M. 1999. Ancestral geographies of the Neolithic. Landscapes, monuments and memory. Routledge. London, New York.

FLEMING A. 2006. Post-processual landscape archaeology: a critique. Archaeological Journal 16: 267-280.

FORTE M. (ed.) 2005. Archaeological landscapes through digital technologies. Proceedings of the 2nd Italy-United States Workshop, Rome, Italy, November 3-5, 2003 Berkeley, USA, May 2005. BAR 1379.

FORTE M., RYAN WILLIAMS P., EL BAZ F., WISEMAN J. (eds.) 2003. The Reconstruction of Archaeological Landscapes through Digital Technologies. Italy-United States Workshop, Boston, Massachusetts, USA, November, 1-3, 2001. BAR 1151.

GHEORGHIU D. 2006a. The formation of tells in the Lower Danube wetlands in the Late Neolithic and Chalcolithic. Journal of Wetland Archaeology 6: 3-18.

2006b. Compactness and void: Addition and subtraction as fundamental operations in South East European Clay Cultures. In Frère-Sautot M-C. (ed.), Des Trous. Structures en creux pre- et protohistoriques. Monique Margoil, Dijon, Baume-les-Messieurs: 151-161. 
2003a. Massive walls and decorated entrances: An archaeological approach to Modern architecture. In Malm G. (ed.), Toward an Archaeology of Buildings. Contexts and concepts. BAR 1186: 119-124.

2003b. Water, tells and textures: A multiscalar approach to Gumelnita hydrostrategies. In D. Gheorghiu (ed.), Chalcolithic and Early Bronze Age Hydrostrategies. BAR IS 1123.

2002a. On palisades, houses, vases and miniatures: The formative processes and metaphors of Chalcolithic tells. In Gibson A. (ed.), Behind Wooden Walls: Neolithic palisaded enclosures in Europe. BAR 1013: 93117.

2002b. Fire and air draught: Experimenting the Chalcolithic pyroinstruments. In D. Gheorghiu (ed.), Fire in archaeology. BAR 1089: 83-94.

in press a. Prehistoric Mandalas: The Semiosis of landscape and the emergence of stratified society in the South-Eastern European Chalcolithic. In Nash G. (ed.), The Semiotic of landscape. BAR IS.

in press $\mathrm{b}$. Built to be fired: The Building and combustion of Chalcolithic dwellings in the Lower Danube and East Carpathian areas. In Nikolova L., Marler, J., Merlini M., Comşa A. (eds.), Circumpontica in Prehistory: Western Pontic Studies. Global Gratitude to Eugen Comşa for His $85^{\text {th }}$ Birth Anniversary. BAR International Series.

GRAHAME M. 2000. Reading space: Social interaction and identity in the houses of Roman Pompeii. A syntactical approach to the analysis and interpretation of the built space. BAR International Series 886. Archaeopress. Oxford.

HAMILAKIS Y., PLUCIENNIK M., TARLOW S. (eds.) 2001. Thinking through the body: archaeologies of corporeality. Kluwer Academic Press. London.

HAMILAKIS Y. et al. on-line http://ads.ahds.ac.uk/catalo gue/adsdata/assemblage/html/index.html

HAMILTON S., WHITEHOUSE R., BROWN K., COMBES P., HERRING E., SEAGER THOMAS M. 2006. Phenomenology in Practice: Towards a Methodology for a 'Subjective' Approach. European Journal of Archaeology 9: 31-71.

HARTZUCHI N., DRAGOMIR I.T. 1957. Sapaturile arheologice de la Brailita, Raport preliminar. Materiale III: 129.

HILLIER B., HANSON J. 1984. The Social logic of space. Cambridge University Press. Cambridge.
HODDER I., HUTSON S. 2006. Reading the past. Current approaches to interpretation in archeology. Cambridge University Press. Cambridge.

BOURDIEU P. 1977. Outline of a theory of practice. Cambridge University Press. Cambridge.

HORNER D. S. 2001. Cyborgs and cyberspace: Personal identity and moral agency. In Munt S. R. (ed.), Technospaces: Inside the new media. Continuum. London: 7184.

HURCOMBE L. 2007. A sense of materials and sensory perception in concepts of materiality. World Archaeology 4: $532-545$.

JEFFREY D. on-line http://www.ucl.ac.uk/iams/jour_24

JOYCE R. 2005. Archaeology of the body. Annual Review of Anthropology 34: 139-158.

KELTERBORN P. 1987. Principles of experimental research in archaeology. Bulletin of Experimental Archaeology 8: $11-14$

KNAPP B. A., ASHMORE W. 1999. Archaeological landscapes: Constructed, conceptualized, ideational. In Ashmore W., Knapp A. B. (eds.), Archaeologies of landscape: Contemporary perspectives. Blackwell, Malden. Oxford: 1-32.

KOTSAKIS K. 1999. What tells can tell: Social space and settlement in Greek Neolithic. In Halstead P. (ed.), Neolithic society in Greece. Sheffield Academic Press, Sheffield: $66-76$.

LAZAR C., PARNIC V. 2007. Date privind unele descoperiri funerare de la Māriuţa - La Movilā. Studii de Preistorie 4: $135-158$.

LLOBERA M. 2001. Building Past Landscape Perception With GIS: Understanding Topographic Prominence. Journal of Archaeological Science 28 (9): 1005-1014.

MARINESCU BÎLCU S., POPOVICI D., TROHANI G., ANDREESCU R. 1997. Archaeological researches at Bordusani Popina (1993-1994). Cercetāri Arheologice (10): 65-69.

MATHIEU J. R. 2002. Introduction: Experimental archaeology. Replicating past objects, behaviors and processes. In Mathieu J. R. (ed.), Experimental archaeology. Replicating past objects, behaviors and processes. BAR IS 1035: 1-12.

MENZE B. H., UR J. A., SHERRATT A. G. 2006. Detection of Ancient Settlement Mounds: Archaeological Survey Based on the SRTM Terrain Model. Photogrammetric Engineering \& Remote Sensing 72 (3): 321-327. 
MIHAILESCU G., ILIE A. 2004. Tellul Gumelnitean de la Geangoiesti (Com Dragomiresti, Jud. Dambovita). Ialomita 4: 71-80.

MORINTZ S. 1962. Tipuri de asezari si sisteme de fortificatie si imprejurimi in cultura Gumelnita. Studii si Cercetari de Istorie Veche 13 (2): 273-284.

NANIA I. 1967. Locuitorii gumelniteni in lumina cercetarilor de la Teiu. Studii si articole de istorie IX: 7-23.

POPOVICI D., RAILLAND Y. 1996-1997. Vivre au bord $d u$ Danube il y a 6500 ans. [cat.] Saint Jean de la Ruelle.

RANDOIN B., POPOVICI D., RAILLAND Y. 1998-2000. Metoda de sāpāturā şi înregistrarea datelor stratigrafice întrun sit pluristratificat: Tellul neo-eneolitic de la Hârşova. Cercetari arheologice X: 199-233.

REYNOLDS P. J. 1999. The Nature of experiment in archaeology. In Harding A. F. (ed.), Experiment and design. Archaeological studies in honour of John Coles. Oxbow Books. 0xford: 156-162.

SAUER C. 0. 1925. The morphology of landscapes. University of California Publications in Geography 2: 19-54.

ŞERBĀNESCU et al. on-line http://www.cimec.ro/ cronica/ $\mathrm{cd} /$ index.htm

SHANKS M., PEARSON M. 2001. Theatre/Archaeology. Routledge. London.

SHERRATT A. 1983. The Eneolithic period in Bulgaria in its European context. In Poulter A. G. (ed.), Ancient Bulgaria (Vol 1). Nottingham University. Nottingham: 188- 198.

STEVANOVIĆ M. 2000. Burned Houses in the Neolithic of South-eastern Europe. In Gheorghiu D. (ed.), Fire in Archaeology. BAR IS 1098: 55-62.

1997. The Age of clay. The Social dynamics of house construction. Journal of Anthropological Archaeology 16: 334-395.

STODDART S. K. F., ZUBROW E. 1999. Changing places. Antiquity 73 (281): 686-688.
TAMISARI F., WALLACE J. 1988. Towards an Experiential Archaeology of Place: From Location to Situation through the body. In Berndt R. M., Tonkinson R. (eds.), Social anthropology and Australian Aboriginal studies: A Contemporary overview. Aboriginal Studies Press. Canberra: 204-223.

THOMAS J. 2006. Phenomenology and material culture. In Tilley C., Keane W., Küchler S., Rowlands M., Spyer P. (eds.), Handbook of Material Culture. Sage. London: 4359.

THOMAS J., BRÜCK J. 2001. Comment: Monuments, power and personhood in the British Neolithic. Journal of the Royal Anthropological Institute 7 (4): 763-767.

TILLEY C. 2004. The materiality of stone. Explorations in landscape phenomenology. Berg. Oxford.

1994. A Phenomenology of landscape. Places, paths and monuments. Berg. Oxford.

TODOROVA H. 1982. Kupferzeitlische Siedlungen in Nordostbulgarien. C. H. Beck. München.

TRINGHAM R. 1992. Households with faces: The Challenge of gender in prehistoric architectural remains. In Gero J., Conkey M. (eds.), Engendering archaeology. Women in Prehistory. Blackwell. 0xford, Cambridge: 93131.

TURNER V. W. 1995. The Ritual Process: Structure and Anti-Structure. Aldine de Gruyter, New York.

1975. Ritual as communication and potency: A Ndembu case study. In Hill C. E. (ed.), Symbols and society: Essays on belief system in action. University of Georgia Press. Athens: 58-81.

TYLER S. A. 1985. Ethnography, intertextuality, and the end of description. American Journal of Semiotics: 8398.

VAN GENNEP A. 1960. Rites of Passage. Routledge. London. 